\title{
INTERNET OF THINGS - CONDITIONS AND OPPORTUNITIES FOR THE DEVELOPMENT IN TOURISM
}

\author{
AGNIESZKA NiEZGODA, ${ }^{1}$ MATYLDA AWEDYK ${ }^{2}$
}

${ }_{1}$ Poznań University of Economics, POLAND

e-mail: agnieszka.niezgoda@ue.poznan.pl

${ }^{2}$ Poznan University of Physical Education, POLAND

e-mail: awedyk@awf.poznan.pl

RECEIVED
ACCEPTED
JEL
CLASSIFICATION

KEYWORDS

ABSTRACT
6 May 2018

4 September 2018

O31, L83, L86

Internet of Things, loT, tourism innovations, tourism development, individualization, personalization

The tourism market is very vulnerable to changes due to the existence of the internet. The observation of buyers' behavior, including e-readiness, prompts agencies to increase the intensity of their online activity. With this potential, which helps to transform many aspects of the travel experience, the Internet of Things (IoT) enables companies to aggregate and integrate large collections of data from multiple sources and instantly personalize the experiences of tourists.

The purpose of this discussion is to explore how we can use new technologies in the form of Internet of Things (IOT) to create personalized offers for tourists. The background to consider is the analysis of the current trends conditioning the use of the Internet of Things in the tourism market, to which authors include phenomena of a general nature: technological and social development and phenomena directly related to tourism: individualization and personalization of offers. The authors hypothesize that the Internet of Things offers huge opportunities in tourism on the supply side, however, tourists do not give up on personalized services. Therefore, one cannot completely give up the contact with the customer. The work is of the reviewed and researched nature. Descriptive and critical analysis methods are also used. In the empirical part, qualitative research was conducted in the form of focused group interviews and quantitative surveys, which included a diagnostic survey using a questionnaire. The research has an exploratory aspect because of the fact that the Internet of Things is still a new issue that needs to be explored more deeply. Survey responses showed that the Internet serves potential tourists to search for travel information and less to book tickets. Researchers also note the shortcomings of spontaneous Internet functions (e.g. the nuisance of "cookies"). 


\section{Introduction}

Globalization causes that the processes of individualization are confronted with the growing importance of world standardization. The process of simultaneous presence of individualization and standardization enables customers to get what they want, and companies can use their knowledge in R\&D. According to R. Butler, "tourists of the 21st century" are different from the tourists of previous epochs, with unprecedented scale and ease of movement to travel (Butler, 2006). The response to these changes is the high level of supply elasticity influenced by changes in the Internet.

As technology is getting cheaper and more efficient, much of the innovation has "shifted" towards the use of smart devices and communication systems to interact with wider environment. Many tourist and hotel brands currently use in their operations, titled in the paper and described in the following part of the work, the phenomenon of the Internet of Things (loT - the Internet of Things) (Ashton, 2009), experimenting with the introduction of related technology to work with the client. With the potential of transforming many aspects of travel, Internet of Things (loT) ${ }^{1}$ allows companies to collect and integrate large sets of data from different sources and instantly personalize them for tourists.

Tourists are more demanding and consume far more information than ever before. Among the trends characterizing the development of tourism can be noted individualization, standardization of services and increasing self-reliance in developing consumer packages. These trends lead to changes in the ways that companies attract customers and satisfy their needs.

The purpose of this paper is to explore ways of using new technologies in the form of Internet of Things (IoT) to create personalized offers for tourists, taking into account the conditions resulting from both transformations of tourism supply (in particular technological changes) as well as demand conditions resulting from changes in consumer behavior in the tourism market.

\section{IoT as a presult of technological changes}

IOT is a term invented and first presented in 1999 by Kevin Aston during a presentation for Procter \& Gamble. The term refers to the future in a world in which all types of electronic devices can be linked together through the Internet. In 2009, K. Asthon wrote: "If we had computers that knew everything about things - using data collected without any of our help - we would be able to track and count everything, significantly reduce waste, losses and costs. We would know when things will need replacements, repairs, whether they are new or their best time has passed. Internet of Things has huge potential, just as the Internet itself was some time ago. Maybe even bigger" (Asthon, 2009).

In the report "Internet of Things in Poland" (http://iab.org.pl/wp-content/uploads/2015/09/Raport-InternetRzeczy-w-Polsce.pdf, access 8.12.2016) the concept of loT is understood as an ecosystem in which objects can communicate with each other, through or without human participation.

The architecture of the loT -based tools, in its simplest form, is based upon:

- objects that can communicate, receive commands or transmit information,

- a communications network that mediates the dialogue,

\footnotetext{
${ }^{1}$ In the later part of the work in some cases, instead of the full name of the phenomenon (Internet of Things) will be used the acronym - that is loT.
} 
- systems and IT solutions processing stored data and transmitting information to devices.

The efficiency and quality of decisions made by the last of the indicated elements is a guarantee of obtaining business value from the use of loT. To achieve this, an appropriate approach to data analysis and the implementation of automation based on the use of mathematical models obtained, i.e. decision rules, are needed to create intelligence in interaction with objects. Building a data-driven support environment in line with these requirements is based on the identification and appropriate support of two different worlds - the knowledge identification area and the area of its operationalization, i.e. the productive implementation.

\section{Changing consumer hehavior in the travel market - individualization and personalization}

The tourist market is very vulnerable to changes resulting from the existence of the Internet. Observing the behavior of buyers - including the willingness to use the network (e-readiness) - encourages the agencies to the growing intensity of Internet activity. According to surveys covering the Polish travel industry, $99 \%$ of tourism businesses use the Internet in their daily activities (Kachniewska, Nawrocka, Niezgoda, Pawlicz, 2012). One of the most important processes influencing the individualization of consumer behavior is the digitization of the tourist market, and in particular the digitization of distribution channels. This allows the consumer to gain the independence of travel arrangements, to compose tourism packages and to obtain detailed information about destinations, eliminating the partial or complete involvement of agents (Kachniewska, 2014). In the travel market, consumers interact with other network users and contribute not only to one company but to a whole community of professionals, service providers and other consumers. As C.K. Prahalad and V. Ramaswamy define (2005), co-creation replaces the exchange process. The condition of this process is the existence of a forum where there may be a dialogue between the consumer and the enterprise and the existence of rules for participation in the forum, which provide for a structured, productive interaction.

The Internet gives the consumer the freedom and opportunity not only to choose elements of the package but also to compare prices (Butler, 2006). This allows the consumer to construct an individual deal by selecting the components of the service in his own package.

It can be assumed that a result of the development of diverse needs and interests and of increasing opportunities for their realization in leisure time will be the individualization of patterns of travel and leisure. As more and more individual travelers are using the internet, their decision on where to go and what kind of service to use depends on the presence of the site on the internet and the opinions of other consumers. Individualization with the development of the internet is becoming an opportunity for new, not-so-popular tourism destinations (Butler, 2006). In order to recognize the conditions of the uses of the Internet of Things on the tourism market, the exploratory research must be carried out.

\section{Methodology of research}

In order to obtain an opinion and understanding of behavior, attitudes and preferences regarding the use of the internet by consumers on the tourism market, focus group interviews and diagnostic surveys were used. The authors realize that the chosen research method is characterized by a lack of representation and it is therefore not possible to estimate the entire population on the basis of the obtained data. It has been recognized, however, that the issue of consumer behavior requires the selection of a qualitative method of data collection. This is a focus group interview, and the results will provide a more detailed explanation of the problem (e.g. information 
background, initiation of ideas, needs detection, hypothesis formulation). The study was conducted in 3 groups of 5 to 8 participants. Respondents were young people, students of one of the universities in Poznan. At a further stage of the study, a questionnaire survey (200 respondents) was used to make a preliminary analysis of the respondents' vulnerability to changes in the Internet. A deliberate selection of the sample is justified by the exploratory nature of the study. It was assumed that young people know the advantages of the Internet and are able to assess the possibilities of its use.

\section{Internet use by tourists - resullts of empirical research}

The topic of discussion in the focus group interviews was the preferred way of organizing the trip during the holidays, taking into account individualization of proceedings. The study assumes that tourists with an individualized approach are more likely to use the internet to organize their travel (Niezgoda, 2010; Sonntag, 2006; Kachniewska, 2014). This allows us to understand the demand for using the internet (and the loT), what is in line with the purpose of this study. In each discussion group, as a primary argument for an individual travel organization, it was reported that it was a "cheaper option". Such a response may be due to the fact that the respondents were students, for whom economic factors are important. The discussion on the implications of the dependencies related to individualization and standardization in the tourism market indicated that "independence" and "self-satisfaction" are very important for young people. The two groups pointed to the fact that a self-organized trip allows one "to plan holidays in terms of their own interests and needs", which is evidence of high awareness of their needs in the group of young consumers.

Another argument on this point was to state that during the self-organized travel "you can learn a lot". In one group, there was an argument called "the control of one's own actions," which proves the consciousness of managing their own time. In another group there was an "ability to negotiate" factor, which was related to the new relations between the consumer and the producer described in the earlier part of the article. In one of the groups appeared the argument that self-organized trip "is not limited by terms and dates" and, in another, it is better to organize your own holiday because travel agency does not have a suitable offer. The last statement indicates high and varied requirements of the consumers described in the theoretical section of this article.

In the second stage of the study, a diagnostic survey was carried out to supplement the knowledge about consumers' behavior determining the use of the internet in tourism. Respondents were also young people studying at the same university. More than half of the respondents $(52.8 \%)$ prefer the individual way of organizing their holidays, only $11.1 \%$ of respondents prefer travel agents and $36.1 \%$ use both ways. Taking into account the possibility of using the Internet, up to $94.4 \%$ of respondents use it "often" or "sometimes". An analysis of the responses to the internet-related activities was conducted. In the search for information about the region, the internet uses $94.4 \%$ of the respondents, $86.1 \%$ for booking transport tickets, and $58.3 \%$ for booking tourist attractions (given options were "often" and "sometimes"). Respondents were asked to rate the importance of the internet in the above 1-3 steps, where 1 means "rarely", 2 "sometimes", 3 "often", and then calculated the average rating to compare what internet activities play the most important role (Table1).

The results show that for the respondents, the internet has the greatest interest during "searching for information about attractions in the region" (2.78) and "looking for accommodation" (2.69). However, these are analytical activities, and the actual use of the internet that is "booking of transport tickets" and "admission tickets to 
tourist attractions", received relatively low assessment, indicating a less frequent use of the Internet (2.44 and 1.78 respectively). This result may point to capabilities of loT, because it helps tourists in real time action.

Table 1. Use of the internet when organizing a tourist trip by respondents (scale 1-3)

\begin{tabular}{ll}
\hline Looking for accommodation & 2.69 \\
Booking transportation tickets & 2.44 \\
Searching for information about the region & 2.78 \\
Tourism attractions ticket reservation & 1.78 \\
\hline
\end{tabular}

Source: authors' elaboration.

In the next group of questions, the respondents evaluated, on a scale of 1-5, if they want the internet to tell them what to do in the next steps (where 1 means the lowest and 5 - the highest desire). Answers to another question showed us that the respondents prefer the internet pointing "what to do next" (3.31) rather than "which site to enter" (2.83). This is a surprising result contrary to the claim of the great autonomy of tourists. However, the overall scores on a 5 point scale is not high. In the case of wanting to use internet hints as to what to do next during the holidays, the highest scores ( 4 and 5 pts) were given by $50 \%$ of the respondents.

Another question asked of respondents was to evaluate, on a scale of $1-5$, scattering them through "cookies" (1 does not distract me at all, 5 - very distracting). Responses were aimed at assessing the general attitude of respondents to the spontaneous effects of the internet and its certain degree of autonomy, which is the basis of the loT. The score (3.89) is quite surprising as it indicates that respondents are distracted by cookies. As much as $91.7 \%$ answered that scatter their "strong" or "very much" (4 and 5 points). This is certainly a limitation, because spontaneous information sent via the internet are perceived by the respondents as annoying and distracting.

\section{The role of the Internet of Things in tourism development - opportunities and constraints}

IOT provides instant access to information and data. Through mobile communications, social media and digitally-created content has completely transformed the way we travel - from booking and buying, to sharing the experiences and impressions by tourists during the travel. Anyone can be an author and a travel writer. Innovations in digital payment methods as well as the ability to quickly verify data have also led to the emergence of new forms of tourism products.

Availability of mobile applications and loT gives the opportunity to improve the various stages of your journey (Buhalis, Amaranggana, 2015):

- in transportation (e.g. navigation and information about the duration of the journey, type of transportation, timetable, price list, information on current promotions),

- in accommodation (e.g. reservation and check-in, maintain contact after using the services of accommodation),

- in gastronomy, (e.g. location information (navigation) and about the restaurant itself, offerings for specialized diets, variety of meals and ingredients),

- in tourism attractions (e.g. cooperation through digital maps, exchange of experiences and information, update of events, recommendation system),

- in support services (e.g. navigation, general information, data updates). 
Use of the loT for the tourism industry also is raising some concerns. These include:

- storage, processing and analysis of data,

- security and privacy of information,

- energy efficiency and consumption at consumer level,

- difficulty in integrating older systems processes into the loT,

- the danger of attacks and hacking attempts to take over the data.

Cisco (2016) publishes annual reports on cyber threats and cybercrime. It is worth noting the basic tendencies which include:

- IR devices can be used to distribute malicious software or become a source of denial of service, which could result in damage, but also in extreme cases, loss of life,

- the ability to correlate information from different sources - car, cell phone, home automation, give a much wider idea of the user than looking for information from one device or application; these details of shopping habits or physical location help launch good, highly targeted and personalized campaigns that were not seen before,

- the so-called "forgotten assets" are increasing the number of abandoned and unmanaged loT devices whose security has not been updated or improved, and as technology advances become an easily accessible form of data.

To combat these threats throughout the continuum of the attack - from attack, during and after, organizations and industries need comprehensive protection. Strengthening the weak links of the security chain is primarily about the ability to create cyber-crime awareness at board level and make cyberbullying an imperative for the company.

\section{Conclusions}

Adaptation of the loT creates tremendous opportunities and challenges. With the continuous flow of information, people can learn more about the world, and at the same time, companies about people. In 2017 it is no longer a discussion on what loT is, but how to implement it most effectively. According to Gartner (2016) and Cisco (2016) $99 \%$ of physical objects that may one day be connected to the network are still unconnected. However, in 2016 with the Internet of Things there are already 6.4 billion devices connected, and this number will increase by 2020 , to almost 21 billion (http://www.gartner.com/newsroom/id/3165317).

The phenomenon of Internet of Things is particularly exciting because of the infinite possibilities that can be created by converting consumer applications to commercial and industrial applications, thus transforming the performance of the various industries, including tourism.

As empirical studies have shown consumers notice the opportunities offered by the use of the internet in making an individual offer. Responses showed that the internet gives potential tourists the ability to search for travel information and less to book tickets.

\section{References}

Ashton, K. (2009). That "Internet of Things". RFiD Journal, 22, 97-114.

Buhalis, D., Amaranggana, A. (2015). Smart Tourism Destinations Enhancing Tourism Experience Through Personalisation of Services. In: I. Tussyadiah, A. Inversini (eds.), Information and Communication Technologies in Tourism (pp. 377-389). International Publishing Switzerland, Springer. 
Butler, R. (2006). Volatile demand for tourism? - We can only market efficiently to what we know, rather than to what we imagine. In: P. Keller, T. Bieger (ed.), Marketing Efficciency in Tourism (pp. 13-22). Berlin: Erich Schmidt Verlag.

Cisco (2016). The Internet of Things: It's not about things, it's about service. Retrieved from: https://www.jasper.com/infographics/ internet-things-its-not-about-things-its-about-service (8.06.2016).

Gartner Says 6.4 Billion Connected 'Things' Will Be in Use in 2016, Up 30 Percent From 2015, Gartner website, 10 November 2015. Retrieved from: http://www.gartner.com/newsroom/id/3165317 (8.06.2017).

Internet Rzeczy w Polsce. Retrieved from: http://iab.org.pl/wp-content/uploads/2015/09/Raport-Internet-Rzeczy-w-Polsce.pdf (8.06.2017).

Kachniewska, M. (2014). Wpływ digitalizacji kanałów dystrybucji na strukturę rynku usług pośrednictwa turystycznego. Wydawnictwo „e-mentor”, 1 (53), 86-91.

Kachniewska, M., Nawrocka, E., Niezgoda, A., Pawlicz, A. (2012). Rynek turystyczny. Ekonomiczne zagadnienia turystyki. Warszawa: Oficyna Wolters Kluwer.

Niezgoda, A. (2010). Nowe trendy w popycie - wyzwanie dla obszarów recepcji turystycznej. In: S. Tanaś (ed.), Nauka i dydaktyka w turystyce i rekreacji (pp. 21-34). Łódź: Łódzkie Towarzystwo Naukowe.

OECD Recommendation on Digital Security Risk Management, 2015, 1 October 2015. Retrieved from: http://www.oecd.org/sti/ ieconomy/digital-security-risk-management.pdf (8.06.2017).

Prahalad, C.K., Ramaswamy, V. (2005). Przyszłość konkurencji. Warszawa: Polskie Wydawnictwo Ekonomiczne.

Sonntag, U. (2006). Volatile tourism consumer = Stable tourism market? Market research results on the demand side of the German holiday market. In: P. Keller, T. Bieger (eds.), Marketing Efficiency in Tourism (pp. 23-34). Berlin: Erich Schmidt Verlag.

Tapscott, D., Williams, A.D. (2008). Wikinomia. O globalnej współpracy, która zmienia wszystko. Warszawa: Wydawnictwa akademickie i profesjonalne.

The Internet of Things: seizing the benefits and addressing the challenges (2016). Retrieved from: http://www.oecd.org/officialdocuments/ publicdisplaydocumentpdf/?cote=DSTI/ICCP/CISP(2015)3/FINAL\&docLanguage=En (8.06.2017).

The OECD Privacy Framework, 10 September 2013. Retrieved from: http://www.oecd.org/sti/ieconomy/oecd_privacy_framework.pdf (8.06.2017).

Cite this article as: Niezgoda, A., Awedyk, M. (2018). Internet of Things - conditions and opportunities for the development in tourism. European Journal of Service Management, 3 (27/1), 173-179. DOI: 10.18276/ejsm.2018.27/1-21. 